\title{
Use of CAMELS Standard in the Assessment of Iraqi Commercial Banks
}

\author{
Ali Abdulhassan Abbas; Alyaa Kareem Obayes; Alyaa Qahtan Abdulkadhim \\ University of Kerbala, College of Administration and Economics, Department of Accounting, Iraq
}

http://dx.doi.org/10.18415/ijmmu.v6i3.812

\begin{abstract}
This current research aims to identify the most important factors affecting Iraqi commercial banks using the CAMELS model. The research was based on a sample of (13) Iraqi commercial banks listed in the Iraqi Stock Exchange. The CAMELS, which consists of (30) equation, was used for the research. The economic inflation and other economic factors affecting the distribution of the financial ratios of the equations on five levels within the CAMELS standard were considered. An algorithm was adopted in the MATLAB program, in addition to adopting statistical categories method, taking the large differences between one ratio and another and adjusting the categories according to the standards of (CAMELS). The research found that Iraqi banks suffer from weaknesses in some sensitivity aspects of market risks and unable to handle the heavy shocks in market risks as well as its low management, other details are mentioned in the summary.
\end{abstract}

Keywords: CAMELS; Iraqi; Commercial Banks

\section{Introduction}

Banks have great importance in the economies of the developing countries because of the banks' large size and the multiplicity of stakeholders from depositors, debtor, and shareholders. The integrity of any national economy depends on the integrity of the banking system. If banks are exposed to any risk, it will directly affect the national economy, thus the importance of banks supervision was increased by the Central Bank and other regulatory bodies. CAMELS is one of the most important globally used standards.

Based on the above, this research aims to identify the most important objectives of applying the CAMELS. It is to evaluate the status of commercial banks and to identify their strengths and weaknesses to find solutions before they widely expand and damage the national economy, and the description and analysis of the system standards, its tools and its impact on performing commercial banks. And to adapt the CAMELS system with the nature of Iraqi commercial banks to develop the banking business. And also to determine the commitment of commercial banks by the international evaluation standards. And work on finding comprehensive financial indicators that help banks to identify the financial performance and predict future performance in the light of financial challenges.

The research is important as it links the components of the CAMELS model to performing Iraqi commercial banks. This model is one of the most important tools used by Central Banks to evaluating and 
control banks to ensure the stability and the safety of the financial system. And to achieve the endurable stability in the commercial banks besides knowing their impact on the national economy. The practical importance of the CAMELS model is highlighted as one of the modern methods in evaluating the performance of commercial banks and it is also used to detect the banking crises before they occur and providing solutions.

The results we reach are of great importance to the regulatory bodies because they give us a deeper understanding of performing commercial banks. And its contribution to the development of the national economy. Therefore, this research opens new horizons because it is based on more comprehensive measures than in previous studies in Iraq.

Based on the above, it can be said that this research shall answer several questions, which is considered a real problem:

1. Are commercial banks committed to achieving capital adequacy?

2. How good are the assets owned by Iraqi commercial banks?

3. Do commercial banks have the ability to bring liquidity for employment and retention?

4. Do commercial banks maintain their balance by achieving sufficient profitability for stability?

5. Do commercial banks contribute to efficiency?

6. How sensitive are the commercial banks to banking errors? and are they able to overcome market risks?

7. What is the effect of the variables related to the bank represented by elements of (CAMELS) on the performance of Iraqi banks?

8. What are the maximum cases of commercial banks and how they can be utilized?

\section{The Theoretical Side}

\section{CAMELS Standard}

Is an effective unified regulatory system to assess the performance of banks to determine their financial viability by identifying their strengths and weaknesses based on six essential elements in order to enable the Supervisory Authority to correct the situation and protect financial integrity (Al-Imam, 2010). The system dates back to November 1979, when it was first used by the Federal Council to examine financial institutions. It is a quick indicator of the true financial position of any bank and the degree of its classification. The standard is one of the direct means of control that is established through field inspection, as the regulatory authorities have worked on the results of the standard (Tourist, 2012), (Debic, 2015).

Here is a detailed explanation of the CAMELS components:

\section{Capital adequacy}

Capital adequacy indicators determine the viability of the financial institutions in face-to-face budget items shocks and take into account the most important financial risks facing financial institutions such as exchange rate risk, credit risk, and interest rate risk (Valahzaghavd \& Bahrami, 2013). The capital adequacy ratio reflects the amount of the Bank's capital to bear unanticipated losses and to meet the obligations.

Capital adequacy is the critical element in addressing the banking risks, which has become a constant supply as a result of the rapid developments in the technology banking field such as electronic banking in general and the Internet in particular, which required a minimum capital adjustment to address the resulted risks (Al Amin, 2010). The type and size of the risk determine the capital level be reduced. It 
represents the capital ratio to its assets with $8 \%$ of the capital, which is greater than the required minimum, and this is included in the Basel II Committee decisions in 2010.

Therefore, in 1999, the Basel Committee submitted some proposals containing new ideas, including the expansion of the capital adequacy accounting framework to meet the objectives of increasing the financial system's safety, security and robustness.

The Central Bank's capital classification is based on a number of factors identified by (Dehreb, 2010), (Sarker, 2005) and (Desta, 2016).

1. The level and quality of the capital and the overall bank financial position.

2. The administration ability to make reserves as additional capital.

3. The direction and size of non-performing loans as well as the adequacy of provisions and assessment reserves.

4. Components of the Bank's budget such as the nature and size of intangible assets, market risks, concentration risks and risks related to non-conventional activities.

5. Risks related to extrabudgetary activities, quality, and strength of revenues and how reasonable dividend distribution is.

6. The ability to enter capital for financing and other sources of capital, including support from the parent company.

7. The Bank's future growth.

\section{Assets Quality}

The assets quality means the type, the risks it faces, its ability to generate returns, the ability to recover them in the agreed aggregate, the collateral adequacy given to its liabilities and the absence of rigid or unproductive assets.

The asset quality rating gives the level of the financial future risks associated with borrowing as well as Portfolio investment, real estate, and off-balance sheet risk. It also shows the classification of the management's ability to identify, measure and control risks. To asset the assessment, we should take into account the adequacy of the debt allocation and the risks based on the value of the investment such as operational risks, corporate's image, strategy, change systems.

Asset quality is particularly important in the evaluation system because it is a critical part of the bank's activity that runs its operations. However, the Bank's acquisition of good assets will result in more income generation and better valuation of both liquidity and capital (Rahim, 2014) (Shaddady \& Moore, 2019).

Asset quality is based on the following issues:

1. The size and intensity of troubled assets for total capital.

2. Size and trends of repayment of overdue loans and actions taken to reschedule them.

3 . Large credit concentrations and the risk of the sole debtor or related debtors.

4. The volume and treatment of the management of staff loans.

5. Effective loan portfolio management in view of the strategies, policies, procedures, controls, and instructions in force.

6. Legal activities related to credit (claim, the pursuit of borrowers).

7. The provisions level made to meet the losses of loans and bad credit.

8. Methods of managing other assets and investing in securities, second assets, bills of exchange ... etc.)

Assets quality also determines the degree of risk in assets and the Bank diversifies into the total loans and geographical areas as well as the investment in securities in order to reduce the risk to which it 
may be exposed. The bank's acquisition of good assets will generate more profits and better valuation of liquidity, management, and capital (Muralidhara \& Lingam, 2017).

(Almahmoud, 2014), (Treaa, 2015), (Handorf, 2016) and (Dincer et al, 2018) noted that asset quality rating reflects the size of current and future risks related to lending, investment portfolio, depreciated real estate and extra-budgetary activities. The classification reflects the management's ability to quantify risk control.

An asset quality assessment must consider the adequacy of debt provisions, the risks that affect the value of investments such as operational risk, market, strategic capacity, and regime change.

An asset quality assessment depends on the following factors:

1. The adequacy of the collateral criteria, the strength of loan management and the relevance of the risk identification.

2. The distribution level of the severity and direction of the classified scheduled debt and nonoperating debt within and outside the budget.

3. Adequacy of debt and investment allocations or valuation reserves.

4. Lending risks arising from or low in off-budget operations such as unfunded credit commitments and lending lines.

5. Diversity and quality of loans and investments portfolio.

6. Undertaking activities related to trading activities.

7. Policies and procedures for loans and investments.

8. The management ability to manage the bank's assets, including debt collection.

9. The adequacy of internal control and information systems.

10. Size and nature of debt documentation.

\section{Management Efficiency}

The ability of the management to control \& manage the banking and credit policy on a sound basis measured by several indicators such as profit trends achieved over several financial periods and the financial institution reports on the internal control systems, which reduces the errors incidents of and irregularities and the ability to attract deposits in addition to the adequacy of the Central Bank in placement. As well as follow the bank decisions and controls governing the banking work issued by the monetary authority. There are some quantitative indicators that can be relied upon:

1. Spending rates.

2. Income ratio of each employee.

3. Expanding the preparation of financial institutions.

(Zagod, 2015), (Williams, 2011)

It reflects the efficiency and ability of the Bank's Board of Directors and its Executive Management in managing risk. Management efficiency will be measured by its ability to control the Bank's operating banks by dividing the Bank's operating expenses on total assets.

We consider the administrative performance as an essential component to judge the Bank's success in achieving its objectives through the interaction of many factors related to the tasks and responsibilities assigned to management, the ability to deal with the developments, environmental and banking changes and to achieve the necessary supervision in this regard.

The following are the most important issues to be considered.

To determine the appropriate classification of management by studying the following factors: 
1. Understand the risks inherent in banking, environmental and economic activities.

2. The financial performance of the bank in view of the quality of the assets, the adequacy of capital, profits, and liquidity.

3. Develop and implement plans, policies, and controls in all key areas of work.

4. Power and convenient function and realization of internal and external audit.

5. Adhering to the laws and the in-force regulations of the Central Bank.

6. Trends towards the bank public interest.

7. Compliance with the laws and legislation and the interaction between the Board of Directors and the General Assembly of shareholders.

8. Application of the principles of acquisition of experience and functional skills to take into account career substitution.

9. Experiences with the concerns and recommendations of the Central Bank and taking into account the accuracy of financial reports and statements.

10. Provide training programs for human resources and attract them effectively and to make sure that it works with high quality.

In general, the Board of Directors should not be involved in the Bank's daily operations, but the Board should provide guidelines for the acceptable risk the level and ensure that appropriate policies, procedures, and practices have been created (Shakara, 2012), (Rozzani \&Rahman\&Dincer, 2013), (Hacioglu, 2015)

The management's ability evaluation shall be based on the following factors:

1. The level and quality of management of the Bank's activities.

2. The ability of the board of directors and management, each according to its competence, to plan and deal with the risks that may arise from changes in working conditions or providing new activities and products.

3. The adequacy of the internal control systems to deal with all risks.

4. Accuracy, timeliness, and effectiveness of information systems and risk control systems.

5. Adequate audit systems and control systems to activate the efficiency of operations.

6. Experiences with recommendations from auditors and control authorities.

7. The extent to which the board of directors and management is an outside influence.

8. Reasonableness of incentive policies and avoidance of individual work.

9. The extent of the administration's desire to take care of the bank's legal interests and community service.

\section{Earnings}

Earnings are the Bank's ability to consistently generate revenues and profits in a balanced manner, as well as implementing policies that reduce public expenditure and track doubtful debts so as not to falter. It also shows the factors influencing earnings and the lending risk which pushes the Bank to make provisions and risks of the financial market that cause the Bank profits changes as a result of its impact on interest rates. Earnings are affected by relying on undisclosed or unnecessary profits. (AlAmin, 2010) (Al-Qaisi, 2017) (Britch et al, 2013).

Earnings achievement is the most important objectives and determinants of the bank performance since profits are the main source for achieving appropriate returns to the bank shareholders. The Bank's management considers profits as an important element to ensure the Bank's continuous performance. It directly affects the strength of the assets and its effectiveness which is measured by determining the return on average assets as the starting point for profit assessment as well as studying and analyzing the following factors: 
1. Profit adequacy to meet losses, enhance capital adequacy and pay reasonable dividends.

2. The quality and installation of net income elements including taxes.

3. Size and trends of various elements of net income.

4. The extent of reliance on exceptional items, securities transactions, high-risk activities or nontraditional income sources.

5. Budget effectiveness and control the income and expenditure items.

6. Provisions adequacy of and loan losses provisions.

The Earnings ratio for taxonomic purposes is usually determined based on the lower performance of the banks of similar characteristics. Focusing on them leads to some results. For example:

The bank may earn very high profits, but the source of profits may come from a one-off or nontraditional (high-risk) activity. In spite of high Earnings, retention of profits remains insufficient to allow capital growth and maintain a guideline to assets.

Earnings reflects the realized profits level of, their contribution to the bank's growth and capital increase (Gilbert et al, 2002).

The profit classification should not only reflect its direction but also the profits quality and the factors affecting them such as credit risk and market risk. The Bank's profits may be subject to change as a result of the change in the interest rate. Also, the quality of the profit is affected by non-recurring profits or tax advantage (Aspal \& Dhawan, 2016).

The revenue quality can also be affected by reliance on non-recurring profits or on a tax advantage. Earnings can also be affected by the inability to access financing needs, inability to control expenditures or adopting a weak strategy (Rauf, 2016) and (ALreda\&Albasry, 2011).

Revenue classification is based on the following factors:

1. The revenues level including the direction and stability of revenues.

2. Ability to consolidate capital accounts through retained earnings.

3. Quality and revenue sources.

4. Banks ratio to operations.

5. The budget system adequacy, forecasting processes, and information risk management.

6 . The adequacy of the volume of debt provisions.

7. Income related to market risks such as interest rate and exchange rate.

\section{Liquidity}

It is the relevance between collecting liquidity as quickly as possible and the best price, and between investing and employing it in a meaningful manner. The bank's liquidity management aims at achieving the following:

1. Making the right decisions regarding the volume of the deposit, which shall reach a certain level as the increasing of the volume of the deposit in the employment absence leads to low earnings.

2. Maintain adequate liquidity ratios for emergency needs.

3. Respecting liquidity ratios set by the monetary authority in addition to setting a minimum liquidity limit in line with the Bank's activities (Al-Tayy and Mahmoud, 2013) (Khodashahi et al, 2018).

Liquidities are particularly important in assessing the Bank financial adequacy because it reflects the Bank's ability to meet its obligations to creditors, especially depositors. Liquidity will be measured by dividing the liquid assets of the Central Bank on total assets. 
The bank's liquidity management shall ensure that the bank is able to maintain an adequate level that liquidity is not at the expense of cost or rely on funds sources that may be available in difficult circumstances.

Liquidity is the ability of the Bank to meet depositors' withdrawals while meeting the needs of borrowers at the same time without having to sell securities with large losses or borrowing at high-interest rates (Rahman \& Islam2018).

When assessing the bank's liquidity, it is necessary to focus on the current level of liquidity as well as the future need. Liquidity management shall ensure adequate liquidity to meet different liabilities on perfect time, taking into account the mismatch between the assets and liabilities in the banking sector or at large-sized financial institutions level (al-Tai and Mahmoud, 2013), (Sarker, 2005) (Ghasempour \& Salami, 2016).

\section{Sensitivity to Market Risk}

Sensitivity to Market Risk reflects the changes in interest rates, exchange rate, commodity price, and stock prices that may adversely affect the Bank's financial position or capital. In assessing sensitivity, consideration should be given to the management's ability to determine the monitoring and control of these risks, the size of the bank, the complexity of these processes, the adequacy of revenues and capital in relation to the level of these risks. For most banks, the main source of this type of risk is non-trading positions and their sensitivity to interest rate risk in large banks. Foreign banking operations can be a source of market risk. In some banks, trading activities are the main source of market risk, (Rostami, 2015), the most important of which are:

\section{Credit risk, 2. Price risk, 3. Liquidity risk}

Market risks refer to the impact of lower asset prices on the Bank's net worth. The reason for the decline is due to several reasons, the most important of which is the portfolio's concentration in certain types of assets or banks' tendency to direct their investments to assets with significant activity such as mortgages.

The sensitivity to market risk reflects the changes in the interest rate, exchange rate and securities prices that negatively affect the financial position of the bank. In light of the developments and challenges in the financial and banking arena, it is necessary to focus on the sensitivity of the assets structure and liabilities and bank's net profits to adverse changes in interest rates and exchange rates, (Rahim, 2014), (Drummond, 2000), (Githinji, 2010).

\section{The advantages of the CAMELS system:} follows:

(Al-Amin, 2010), (Dhehrb, 2010) and (Dang, 2010) pointed to a number of advantages as

1- Banks classification according to a unified standard.

2. Standardize reporting.

3. Shortening the evaluation time by focusing on six items and not stabilizing efforts in evaluating unnecessary items

4. Dependence on digital assessment rather than the reporting style, which reduces the volume of the report and increases their credibility. 
5- To make a comprehensive classification of the banking system as a whole according to a unified approach and analyzing the results horizontally for each bank separately and for each similar group of banks and vertically for each of the six banking performance elements.

6. CAMELS are less costly than office software. future.

7. This is a standard that is truly capable of isolating risk factors that may lead to problems in the

8. The results of this system shall be based on the supervisory decisions and the procedures following the evaluation.

\section{The disadvantages of the CAMELS system:}

(Al-Imam (2010) and (Dervizpodiera, 2008) pointed to a number of disadvantages:

1. The choice of the financial ratios, on which the Standard is based, is based on personal judgment and not on statistical assumptions. Some scientific research has found other financial ratios that are more efficient and have a greater impact on the Bank financial position than the ratios currently used by the Standard. It may be useful to replace current ratios with new ratios, which may improve the standard efficiency.

2. The standard is based on the bank's classification into similar groups according to the size of the assets, since the average values of the used ratios reflect the whole group, however, the average differs significantly from one bank to another within the same group and therefore does not reflect the reality of the group.

3. The Standard measures the performance based on the other banks constituting the relative group. In case of any structural change in that group performance or the performance of the banking system as a whole, valuation indicators are not normally changed accordingly when calculating the final ratings.

4 - The system gave weights to all elements and it is difficult to install them throughout the evaluation periods without giving consideration to the variables and this may also reduce the standard accuracy and the importance of its results.

5. In the case of a significant change in the assets size of a particular bank, which puts it in another relative group larger or smaller than the previous relative group and may change markedly in the assessment weights and the questioned bank classification, although the indicators of its financial position has not changed, but confined to the change in Assets size only.

\section{Banking classifications by CAMELS method}

Each (Dahir, 2015) and (Al-Qaisi, 2017) refers to the bank's classification according to the CAMELS standard as in Table (1):

Table (1) Banks Classification by CAMELS standard

\begin{tabular}{llll}
\hline Classification & $\begin{array}{l}\text { Degree } \begin{array}{r}\text { of } \\
\text { classification }\end{array} \\
\text { Strong }\end{array} 1$---- 1.4 & \multicolumn{1}{c}{ Bank position } & \multicolumn{1}{c}{ Control Procedure } \\
\hline Satisfactory & $1.5----2.4$ & Relatively true with some deficiencies & Treatment of negatives \\
\hline Fair & $2.5----3.4$ & $\begin{array}{l}\text { Shows the elements of weakness and } \\
\text { strength }\end{array}$ & $\begin{array}{l}\text { Control and follow-up to the } \\
\text { Bank }\end{array}$ \\
\hline Margin & $3.5----4.4$ & Risk may lead to failure & $\begin{array}{l}\text { Field reform and follow-up } \\
\text { program }\end{array}$ \\
\hline Unsatisfactory & $4.5----5$ & Very dangerous & $\begin{array}{l}\text { Permanent control+ } \\
\text { supervision }\end{array}$ \\
\hline
\end{tabular}


The classification grades are usually divided into the six components of the mentioned standard according to the following weights for each system element or according to the monetary authority as shown in Table (2)

Table (2): CAMELS elements Weights

\begin{tabular}{lllllll}
\hline item & C & A & M & E & L & S \\
\hline weight & $20 \%$ & $20 \%$ & $25 \%$ & $15 \%$ & $10 \%$ & $10 \%$ \\
\hline
\end{tabular}

Shakara (2012), (Dahrib, 2010), (Masoud et al, 2016) referred to a detailed explanation of each classification

1. Strong classification: This rating is given to a bank that is robust in all respects and has no weaknesses. They are usually minor and can be dealt with by the Board of Directors of the bank. The banks that fall within this classification are strong banks and then have the ability to resist any external situation, such as economic instability and also these banks are fully committed to the laws and regulations. It has strong performance and efficient risk management and does not pose any concern to regulatory authorities. These banks have liquid assets to normally meet the volatility of deposits and loans demand, with limited reliance on interbank borrowing for liquidity needs.

2. Satisfactory classification: The banks in this group are basically solid but suffer from minor problems fall within the control of each board. These banks are stable and able to deal with economic fluctuations. These banks are largely committed to regulations and laws. The risk management of these banks is somehow satisfactory compared to the bank's size and the complexity of its operations. There is no material concern by the regulatory authorities and therefore the intervention of the supervisory authority is usually limited. These banks include weaknesses in one or more factors and these weaknesses can be corrected by applying a reasonable time frame. There is a little likelihood that these risks will affect the revenues level and capital. The revenues level and capital are sufficient to cover market risks taken by the Bank.

3. Fair classification: Banks within this group are a concern for regulatory authorities because of some of the above classification components. These banks suffer from some weaknesses ranging from medium to severe. Bank management can reduce the ability or willingness to deal with weaknesses within a specific time frame. Such banks are usually unable to cope with business fluctuations and are more susceptible to external conditions than those classified as $(1,2)$ and are not compliant with a reasonable degree of regulation. The risk management for these banks is also less satisfactory. In addition to the banks need of the regulatory authorities. These banks' failure is uncertain. These banks include major weaknesses that may turn out to be worse, requiring regulatory oversight to ensure management reform.

4. Marginal classification: The banks that fall within this group suffer from unsafe and unsustainable practices and there are serious administrative and financial problems that can lead to unsatisfactory performance. The banks problem ranges from acute to critical. The problems and weaknesses are not satisfactorily dealt with by the Board of Directors of the bank. The banks within this group are unable to deal with working fluctuations and do not comply with the banks' laws and regulations. The risk management of these banks is not acceptable compared to the bank size, complexity, and risk degree. These banks require considerable control by the regulatory authorities; in return, these banks are required to take the necessary steps to correct the situation. These banks represent a threat to the Deposit Guarantee Corporation and these banks' failure probability is significant if the weaknesses are not satisfactorily addressed. These banks face severe liquidity problems that require immediate action to ensure that the bank meets its current needs and plans for short-term and unanticipated liquidity needs. 
5. Unsatisfactory classification: Banks that fall within this category suffer greatly from unsafe and unsustainable practices and suffer from poor performance and significant risk management weaknesses in terms of the bank's size, complexity, and risk. And it represents a major concern for the regulatory authorities. The size and degree of severity of the problems lie outside the administration's ability to adjust and correct them. These banks need to emergency assistance if they want continue. These banks also need constant control and its failure probability is magnificent. This type of bank requires the central bank's help to prevent the collapse of the bank because of its inability to meet the creditors and depositors' needs.

\section{Methodology}

\section{Measurements used in the research}

The CAMELS standard, which was adopted by Rostami (2015), was relied on. And it's used on a sample of Iraqi commercial banks listed in the Iraqi market exchange and is all explained in detail with a brief explanation as in the tables.

Table (3) Capital Adequacy

\section{Capital (C)}

TIER1= Total shareholders 'equity/Total risk- TIER2 $=$ Total complementary capital/Total weighted assets risk-weighted assets

TIER1: It measures bank's financial strength TIER2: It measures the complementary capital in dealing with the losses in risk-weighted capacity addressing losses in risk-weighted assets and as these ratio increases, the Bank's assets and as the percentage increases, it ability to offset losses arising from risks such as indicates the bank's strength to address losses trading, investing and lending increases too. without affecting its financial position

CAR= Total capital base/ Total complementary $\quad$ TLTE $=$ Liabilities/ Equity capital

CAR: The this ratio increasing is an evidence of the strength of the bank's core capital and a rise in the IPO and retained earnings

TLTE: The lower the ratio, the greater the Bank's ability to meet its liabilities and its ability to pay all its debts to shareholders in the Bank if the bank is liquidated.

TDTE=Deposits/Equity

TDTE: Whenever this ratio is low, it indicates the bank's ability to meet all amounts of deposits if it was withdrawn at one time from the bank and is not affected by its financial position in case of large withdrawals

Table (4) Assets Quality

\section{Assets quality (A)}

EATA= Total current assets /Total assets

EATA: It measures the amount of underlying assets, most of which are liquid assets, and the higher the ratio, the greater the strength of the bank's financial position in generating profits

TBPA=Bank shares of income/Total assets TBPA: It measures the total amount of the bank's income to the total assets and the

\section{DA= Deposits/Total assets}

DA: It measures the deposits increasing rate to the total assets. The increasing of this ratio is a good indicator and evidence of the deposits' accumulation and non-investment

TAEA= Fix assets/Equity

TAEA: The rise in this ratio is evidence that the bank has fixed assets in excess of shareholder 
greater the percentage, it is a good sign of the value and this is a good indicator bank's ability to generate high income

FIX = Fix assets/Total assets

FIX: The rise in this index is not good, it is evidence of the lack of liquid assets on the short term

Table (5) Management Efficiency

Management quality (M)

TPTB=Net profit/Number of branches

TPTB: The higher the ratio over the years is a good indicator and if the number of branches increases but the ratio don't increase, this is evidence that the new branches did not benefit the bank

TATB = Total assets/Number of branches TATB: The rise in this ratio is a good indicator in terms of the total amount of assets and if there is a decrease in the indicator ratio, this is an evidence of the assets' depreciation or that newly opened branches did not achieve an increase in total assets

TFTB= Total loans/Number of branches

TFTB: The increase in this index makes the bank faces an embarrassing situation in the event of a financial crisis, it will be unable to avoid the crisis in case of lenders objection and the failure to pay their money.
TLTB $=$ Total liabilities/Number of branches

TLTB: The lower the ratio, the better the ratio of liabilities to the number of branches, so each branch will be able to meet its liabilities well. Without affecting its financial position

\section{TDTB $=$ Total deposits/Number of branches}

TDTB The increase in this index is not good, indicating that there are deposits that are not well invested

Table (6) Earnings

Earnings (E)

FTI=Fees and commissions/Total Income

FTI: The rise of this index is a positive sign for the bank, which is an evidence of the abundance of services provided by the bank and is charged with financial commissions

$\mathbf{P F}=$ Loan income/Loans

PF: The rise in this index is a good sign that customers continue to repay the loan amount with interest. In case of decline, it indicates the reluctance of customers to pay the money and affects the financial position of the bank

OI= Deposit Cost/Total Income

OI: The rise in this ratio is not a good indicator and indicates the high cost of deposits relative to gross income

\section{PD= Deposit cost/Deposit}

PD: The rise in this ratio is not good, it indicates a high cost incurred by banks in order to keep deposits

\section{PP= Loan income/Deposit cost}

PP: The rise in this ratio is a good sign of higher loan income on the cost of deposits. It shows that there is a movement in deposits and is granted in loans form. 
Table (7) Liquidity

Liquidity (L)

INT $=$ (Investment/Total assets)

INT: The rise of this ratio is a good indicator of the increase in banking investments relative to total assets

VTC $=$ Current liquidity/Deposits

VTC: The rise of this ratio is a good indicator of the bank's high liquidity and the bankability to meet the amount of the deposit

LI=Liquidity/Assets

LI: The rise in this ratio is a good indicator of the bank's ability to generate large liquidity compared to its total assets

\section{OTA=Security/Total assets}

OTA: The rise in this ratio is a good indicator of the bank's increasing in securities investments relative to the total assets

VD=Current liquidity/(Demand deposits)

VD: The rise in this ratio is a good sign and evidence of the bank's ability to face large and sudden withdrawals in current deposits

Table (8) Sensitivity to Market Risk

\begin{tabular}{ll}
\hline Sensitivity and risk (S) & NPL2=(Bad debts + Overdue)/Loans \\
\hline NPL=Doubtful debts/Loans & NPL2: The rise in this ratio is not good because \\
\hline $\begin{array}{l}\text { NPL: The increase in this ratio is not a good } \\
\text { indicator because of the debtors reluctance } \\
\text { to pay loan installments }\end{array}$ & $\begin{array}{l}\text { of the high ratio of the bad debt or the delay in } \\
\text { loan installments payment }\end{array}$ \\
\hline PROV= Provisions of loan/Loans & OPER=Long term deposits/Deposits \\
\hline PROV: The increase in this ratio is a good & $\begin{array}{l}\text { OPER: The rise in this ratio is a positive sign } \\
\text { indicator and indicates provisions existence } \\
\text { and evidence that the bank has long-term }\end{array}$ \\
of to face default in the repayment of the guaranteed investments \\
loan
\end{tabular}

Table (9) provides a brief description of the terms used in the research scale

\begin{tabular}{|l|l|}
\hline \multicolumn{1}{|c|}{ index } & \multicolumn{1}{c|}{ Details } \\
\hline $\begin{array}{l}\text { Total } \\
\text { shareholders } \\
\text { 'equity }\end{array}$ & $\begin{array}{l}\text { Shareholders' equity is often referred to as the company's book value and comes from } \\
\text { two main sources, the first and original source is the money invested in the company, } \\
\text { besides any additional investments made thereafter, and the second source is the } \\
\text { retained earnings the company able to collect over time through its operations }\end{array}$ \\
\hline $\begin{array}{l}\text { Total risk- } \\
\text { weighted } \\
\text { assets }\end{array}$ & $\begin{array}{l}\text { are the amount of capital that is required within banks based on a percentage of the } \\
\text { assets, weighted by risk }\end{array}$ \\
\hline $\begin{array}{l}\text { Total capital } \\
\text { base }\end{array}$ & $\begin{array}{l}\text { can refer to the capital acquired during an IPO, or the additional offerings of a } \\
\text { company, plus any retained earnings }\end{array}$ \\
\hline $\begin{array}{l}\text { Total } \\
\text { complementary } \\
\text { capital }\end{array}$ & $\begin{array}{l}\text { Including (foreign exchange differences + fair value reserve for financial assets } \\
\text { through equity, up to 45\% if it is positive or fully repaid if negative + general bank } \\
\text { risk reserve) + medium or long-term supporting loans with common characteristics } \\
\text { between equity instruments Debt under certain conditions + Unregulated reserves }+ \\
\text { Revaluation reserves + Reserves to counter bad debts + Securities }\end{array}$ \\
\hline Liabilities & $\begin{array}{l}\text { as a company's legal financial debts or obligations that arise during the course of } \\
\text { business operations. ... Recorded on the right side of the balance sheet, liabilities }\end{array}$ \\
\hline
\end{tabular}




\begin{tabular}{|c|c|}
\hline & clude loans, accounts payable, mortgages, deferred revenues, and accrued expenses \\
\hline Equity & $\begin{array}{l}\text { which represents the amount of money that would be returned to a company's } \\
\text { shareholders if all of the assets were liquidated and all of the company's debt was } \\
\text { paid off }\end{array}$ \\
\hline Deposits & $\begin{array}{l}\text { consist of money placed into banking institutions for safekeeping. These deposits are } \\
\text { made to deposit accounts such as savings accounts, checking accounts and money } \\
\text { market accounts. The account holder has the right to withdraw deposited funds, as set } \\
\text { forth in the terms and conditions governing the account agreement. }\end{array}$ \\
\hline $\begin{array}{ll}\text { Rate } & \text { base } \\
\text { assets } & \end{array}$ & $\begin{array}{l}\text { refers to the underlying assets giving value to a company, investment or loan. The } \\
\text { asset base is not fixed. It will appreciate or depreciate according to market forces, or } \\
\text { increase and decrease as a company sells or acquires new assets } \\
\text { Principal assets = Cash and balances in the Central Bank + Balances with banks and } \\
\text { other financial institutions + Net direct credit facilities + Financial assets at fair value } \\
\text { through comprehensive income + Financial assets at amortized cost }\end{array}$ \\
\hline Total Assets & $\begin{array}{l}\text { include anything a company owns that has monetary value, even if it can't be readily } \\
\text { sold. They are split into two classes -- current assets, which refers to assets that a } \\
\text { company can (or will) sell within one year, and long-term assets, which are the assets } \\
\text { a company cannot (or doesn't plan to) sell within a year. Examples of a company's } \\
\text { assets include, but are not limited to Cash and equivalents, Investments, such as } \\
\text { equities or debt securities, Equipment, Inventory, Real estate, Accounts receivable, } \\
\text { Intangible assets, such as goodwill }\end{array}$ \\
\hline Fixe & $\begin{array}{l}\text { also known as tangible assets or property, plant and equipment (PP\&E), is a term } \\
\text { used in accounting for assets and property that cannot easily be converted into cash. } \\
\text { This can be compared with current assets such as cash or bank accounts, described as } \\
\text { liquid assets }\end{array}$ \\
\hline $\begin{array}{l}\text { Bank shares of } \\
\text { income }\end{array}$ & It measures the Bank's share of generated total income during the financial year \\
\hline $\begin{array}{l}\text { Fees and } \\
\text { commissions }\end{array}$ & $\begin{array}{l}\text { A commission is a fee paid to a bank in exchange for an in-service or completing a } \\
\text { sale transaction. The commission may be structured as a flat fee, or as a percentage of } \\
\text { the revenue, gross margin, or profit generated by the sale. } \\
\text { fee definition: an amount of money paid for a particular piece of work or for a } \\
\text { particular right or service. }\end{array}$ \\
\hline Total Income & It represents revenue from all sources, and it is before deducting the costs and tax \\
\hline Deposit cost & $\begin{array}{l}\text { Which are the costs borne by the bank due to the retention of deposits and the } \\
\text { increase in the cost of the deposit is not a good indicator }\end{array}$ \\
\hline Loan i & $\begin{array}{l}\text { Which is the income amount that the bank receives from the loans granted to } \\
\text { customers, it represents the on-time granted loan interest }\end{array}$ \\
\hline Loans & Is the amount of money the Bank gives to customers for interest and guarantees \\
\hline Security & $\begin{array}{l}\text { Investment in securities Shares, bonds and treasury bonds that are characterized by } \\
\text { their ability to switch to quickly liquidity as needed }\end{array}$ \\
\hline $\begin{array}{l}\text { Demand } \\
\text { deposits }\end{array}$ & $\begin{array}{l}\text { They are current and demand deposits that can be withdrawn by the client at any time } \\
\text { and without a fixed limit for the withdrawn funds amount. The bank does not pay any } \\
\text { interest }\end{array}$ \\
\hline $\begin{array}{l}\text { Current } \\
\text { liquidity }\end{array}$ & $\begin{array}{l}\text { Bank liquidity means the commercial bank's ability to pay in cash for all its trade } \\
\text { obligations and to respond to credit requests or to grant new loans. This requires the } \\
\text { availability of liquid cash at the bank or the possibility of obtaining it by liquidating } \\
\text { some of its assets }\end{array}$ \\
\hline Investment & $\begin{array}{l}\text { It is a capital used in the production or provision of services or goods. It may be a } \\
\text { fixed investment such as preferred stocks and bonds, or a variable investment such as } \\
\text { property ownership. Investment is defined as the assets that individuals and }\end{array}$ \\
\hline
\end{tabular}




\begin{tabular}{|l|l|}
\hline & enterprises purchase in order to obtain current or future income. \\
\hline Doubtful Debts & $\begin{array}{l}\text { are those debts which a business or individual is unlikely to be able to collect. The } \\
\text { reasons for potential non-payment can include disputes oversupply, delivery, the } \\
\text { condition of the item or the appearance of financial stress within a customer's } \\
\text { operations. }\end{array}$ \\
\hline $\begin{array}{l}\text { Provisions of } \\
\text { loan }\end{array}$ & $\begin{array}{l}\text { A loan loss provision is an expense set aside as an allowance for uncollected loans } \\
\text { and loan payments. This provision is used to cover a number of factors associated } \\
\text { with potential loan losses, including bad loans, customer defaults, and renegotiated } \\
\text { terms of a loan that incur lower than previously estimated payments }\end{array}$ \\
\hline $\begin{array}{l}\text { Long-term } \\
\text { deposits }\end{array}$ & $\begin{array}{l}\text { Refer to terms of more than 12 months. You'll usually have the option to put your } \\
\text { money away for between one and five years. As an incentive to leave your money } \\
\text { untouched for a longer period, long-term deposits usually offer higher interest rates } \\
\text { than the shorter-term ones. }\end{array}$ \\
\hline
\end{tabular}

In order to apply the CAMELS standard to the Iraqi banks, it will be necessary to determine the location of each ratio of the indicators found within the degree to which they correspond, which are from 1 to 5 . As we have already seen, the number 1 represents the excellent position of the bank. Class 5 is the lowest level, as shown in Table (10).

The distribution of the reached percentages within these five degrees of the CAMELS standard requires a lot of effort and time to put them in a table that fits with the variables in the Iraqi environment and take the current inflation rate and the amount of national income and other indicators related to economic ratios. As well as the use of a number of statistical equations in relation to the categories distribution in order to distribute each proportion into five categories, taking into account the differences and financial mutations in some ratios and taking into account the highest value and subtracting from the lowest value for each equation and the teams begin to distribute it in five categories and then we undertake In the end, Table 10 was prepared, on the basis of which each percentage was distributed within the appropriate degree.

A special algorithm was developed within the MATLAB program and all the data on the CAMELS scale were included in order to assign each percentage to each equation Etc. (1 to 5) based on Table 10 and all six of the CAMELS six indicators to which they apply. This algorithm has been developed to match the data entered in 2017. It should be borne in mind that these percentages in Table (10) change each year in accordance with economic conditions and inflation rates. Because they have a strong impact on the scale accuracy of the. Through the algorithm that has been developed can be constantly updated and locate the bank within the CAMELS standard.

With this algorithm, it can be linked to the bank database and the data is automatically generated. The bank manager can tell the degree to which the bank will be within the CAMELS standard at any time. In the future, we hope that this program, which we are still working on, will be linked to the Iraq Stock Exchange database so that the data can be automatically spoken within the program without having to be re-entered. The code for each budget variable and income statement is given to matching the program codes and the data is automatically calculated and the degree to which each bank will be calculated at a fast pace for decisions to be made quickly. This requires artificial intelligence to automatically transfer data from the Iraq Stock Exchange database to the CAMELS database, which we have prepared and link directly with the CBI so that the central bank can conduct ongoing monitoring. Where data are automatically generated when the Bank inserts data each year and sends them to the Iraqi Stock Exchange. (Caglar, 2018), (Rostami, 2015), (Brandimarte, 2013), (Kienitz \& Wetterau, 2012) (McCarthy, 2018). 
Table (10) shows the details of the conversion of the CAMELS financial ratios to the progressive scale, which starts from 1 strong to 5 weak and for each equation used after relying on many previous studies to develop these ratios that are appropriate to the Iraqi financial environment.

\begin{tabular}{|c|c|c|c|c|c|c|}
\hline No. & Equations & 1 & 2 & 3 & 4 & 5 \\
\hline 1 & TIER1 & More than $98 \%$ & $80 \%---98 \%$ & $70 \%---80 \%$ & $50 \%---70 \%$ & Less than $50 \%$ \\
\hline 2 & TIER2 & More than $96 \%$ & $78 \%--96 \%$ & $78 \%--65 \%$ & $65 \%--59 \%$ & Less than $59 \%$ \\
\hline 3 & CAR & More than $93 \%$ & $88 \%--93 \%$ & $88 \%--78 \%$ & $78 \%--55 \%$ & Less than $55 \%$ \\
\hline 4 & TLTE & Less $32 \%$ & $32 \%--44 \%$ & $44 \%--58 \%$ & $58 \%--80 \%$ & More than $80 \%$ \\
\hline 5 & TDTE & Less $39 \%$ & $39 \%--47 \%$ & $47 \%--59 \%$ & $59 \%--72 \%$ & More than $72 \%$ \\
\hline 6 & EATA & More than $90 \%$ & $90 \%--74 \%$ & $74 \%--58 \%$ & $58 \%--47 \%$ & Less than $47 \%$ \\
\hline 7 & DA & Less than $46 \%$ & $46 \%--51 \%$ & $51 \%--63 \%$ & $63 \%--81 \%$ & More than $81 \%$ \\
\hline 8 & TBPA & More than $94 \%$ & $94 \%--85 \%$ & $85 \%--73 \%$ & $73 \%--55 \%$ & Less than $55 \%$ \\
\hline 9 & TAEA & More than $89 \%$ & $89 \%--81 \%$ & $81 \%--65 \%$ & $65 \%--50 \%$ & Less than $50 \%$ \\
\hline 10 & FIX & Less than $50 \%$ & $50 \%--62 \%$ & $62 \%--76 \%$ & $76 \%--84 \%$ & More than $84 \%$ \\
\hline 11 & TPTB & $\begin{array}{l}\text { More than } 11 \\
\text { Billion }\end{array}$ & 11--7 Billion & 7--6 Billion & 6-3 Billion & $\begin{array}{l}\text { Less than } 3 \\
\text { Billion }\end{array}$ \\
\hline 12 & TATB & $\begin{array}{l}\text { More than } 48 \\
\text { Billion }\end{array}$ & $48-30$ Billion & $30-20$ Billion & $20-8$ Billion & $\begin{array}{l}\text { Less than } 8 \\
\text { Billion }\end{array}$ \\
\hline 13 & TLTB & $\begin{array}{l}\text { Less than } 7 \\
\text { Billion }\end{array}$ & 7-11 Billion & 11-20 Billion & $20-75$ Billion & $\begin{array}{l}\text { More than } 75 \\
\text { Billion }\end{array}$ \\
\hline 14 & TDTB & $\begin{array}{l}\text { Less than } 7 \\
\text { Billion }\end{array}$ & 7-13 Billion & 13-26 Billion & 26-38 Billion & $\begin{array}{l}\text { More than } 38 \\
\text { Billion }\end{array}$ \\
\hline 15 & TFTB & $\begin{array}{l}\text { Less than } 49 \\
\text { billion }\end{array}$ & $49-57$ Billion & 57-67 Billion & $67-82$ Billion & $\begin{array}{l}\text { More than } 82 \\
\text { Billion }\end{array}$ \\
\hline 16 & FTI & More than $85 \%$ & $85 \%--73 \%$ & $73 \%--60 \%$ & $60 \%--43 \%$ & Less than $43 \%$ \\
\hline 17 & PF & More than $90 \%$ & $90 \%--80 \%$ & $80 \%--60 \%$ & $60 \%--33 \%$ & Less than $33 \%$ \\
\hline 18 & PD & Less than $30 \%$ & $30 \%--35 \%$ & $35 \%--42 \%$ & $42 \%--66 \%$ & More than $66 \%$ \\
\hline 19 & PP & More than $90 \%$ & $90 \%--82 \%$ & $82 \%--60 \%$ & $60 \%--35 \%$ & Less than $35 \%$ \\
\hline 20 & OI & Less than $20 \%$ & $20 \%--37 \%$ & $37 \%--44 \%$ & $44 \%--69 \%$ & More than $69 \%$ \\
\hline 21 & INT & More than $86 \%$ & $86 \%--71 \%$ & $71 \%--60 \%$ & $60 \%--45 \%$ & Less than $45 \%$ \\
\hline 22 & VTC & More than $90 \%$ & $90 \%--80 \%$ & $80 \%--70 \%$ & $70 \%--49 \%$ & Less than $49 \%$ \\
\hline 23 & OTA & More than $93 \%$ & $93 \%--82 \%$ & $82 \%--71 \%$ & $71 \%--49 \%$ & Less than $49 \%$ \\
\hline 24 & VD & More than $90 \%$ & $90 \%--80 \%$ & $80 \%--72 \%$ & $72 \%--52 \%$ & Less than $52 \%$ \\
\hline 25 & LI & More than $88 \%$ & $88 \%--77 \%$ & $77 \%--60 \%$ & $60 \%--46 \%$ & Less than $46 \%$ \\
\hline 26 & NPL & Less than $10 \%$ & $10 \%--15 \%$ & $15 \%--44 \%$ & $44 \%--60 \%$ & More than $60 \%$ \\
\hline 27 & NPL2 & Less than $12 \%$ & $12 \%--23 \%$ & $23 \%--46 \%$ & $46 \%--62 \%$ & More than $62 \%$ \\
\hline 28 & PROV & More than $88 \%$ & $88 \%--78 \%$ & $78 \%--67 \%$ & $67 \%--48 \%$ & Less than $48 \%$ \\
\hline 29 & OPER & More than $90 \%$ & $90 \%--80 \%$ & $80 \%--70 \%$ & $70 \%--40 \%$ & Less than $40 \%$ \\
\hline 30 & DD & Less than $35 \%$ & $35 \%--47 \%$ & $47 \%--65 \%$ & $65 \%--80 \%$ & More than $80 \%$ \\
\hline
\end{tabular}

\section{The sample}

A sample was taken from Iraqi commercial banks listed in the Iraqi Stock Exchange. The remainders that were not selected are due to the lack of data for the study for 2017, although we live in 2019, so it has been neglected. The following table shows the banks that have been taken and the banks that have been neglected for not following the transparency principle in providing full data to the Iraqi securities market. Or because there is a lack of necessary data. 
Table (11): Sample of the study selected from the rest of the banks with the number of branches in Iraq No. Iraqi banks listed in the market for securities

\section{Code}

Number of

Sample branches in

\begin{tabular}{clccc}
\hline 1 & Ashur International Investment Bank & BASH & 8 & yes \\
\hline 2 & Bank of Babylon & BBAY & 13 & yes \\
\hline 3 & Bank of Baghdad & BBOB & 34 & yes \\
\hline 4 & Commercial Bank of Iraq & BCOI & 25 & yes \\
\hline 5 & Tigris and Euphrates Development and Investment Bank & BDFD & & no \\
\hline 6 & Dar AL- Salaam Investment Bank & BDSI & & no \\
\hline 7 & Economy Bank for investment & BEFI & & no \\
\hline 8 & Erbil Investment \& Finance Bank & BERI & & no \\
\hline 9 & Gulf Commercial Bank & BGUC & 20 & yes \\
\hline 10 & Iraqi Investment Bank & BIBI & 16 & yes \\
\hline 11 & International Development Bank for Investment and Finance & BIDB & & no \\
\hline 12 & Middle East Investment Bank & BIME & 15 & yes \\
\hline 13 & Kurdistan International Bank & BKUI & 5 & yes \\
\hline 14 & Mosul Bank for Development and Investment & BMFI & & \\
\hline 15 & Al Mansour Investment Bank & BMNS & 9 & yes \\
\hline 16 & National Bank of Iraq & BNOI & 10 & yes \\
\hline 17 & North Bank for Finance and Investment & BNOR & & no \\
\hline 18 & Iraqi Credit Bank & BROI & & no \\
\hline 19 & Region Trade Bank for Investment and Finance & BRTB & & no \\
\hline 20 & Sumer Commercial Bank & BSUC & 10 & yes \\
\hline 21 & Bank across Iraq for investment & BTRI & & no \\
\hline 22 & United Investment Bank & BUND & 26 & yes \\
\hline 23 & Bank Union of Iraq & BUOI & 18 & yes \\
\hline 24 & Al Warka Investment Bank & BWAI & & no \\
\hline 25 & United Arab financial transfer & MTUA & & no \\
\hline & & & &
\end{tabular}

\section{Hypotheses}

1. The implementation of the CAMELS standard, which leads to the evaluation of banking and increasing profits

2. Apply the CAMELS standard to achieve the quality of banking assets.

\section{Practical side}

\section{Capital Adequacy Indicators}

It is clear from Table (12) that most of the banks in the research sample did not reach the highest level, therefore are t not within the strong classification. But was limited between the satisfactory and fair classification. This means that banks are unable to withstand the strong shocks of exchange rate risk, credit risk, and interest rate risk, and in this case, all banks are required to raise their capital. Because the Iraqi financial environment is unstable, especially within the political transformations experienced by the region, making it in the future unable to withstand any strong shock in the economy, especially banks that fall within the reasonable level will be most vulnerable to exposure to risk which requires the Central Bank to monitor and follow up these banks. But in turn, these banks are able to cope with only minor economic changes. 
Table (12) Capital adequacy index

\begin{tabular}{lcccccccc}
\hline No. & Banks & TIER1 & TIER2 & CAR & TLTE & TDTE & Average & Classification \\
\hline $\mathbf{1}$ & BASH & 2 & 3 & 2 & 4 & 3 & 2.3 & Satisfactory \\
\hline $\mathbf{2}$ & BBAY & 3 & 3 & 2 & 4 & 4 & 3.2 & Fair \\
\hline $\mathbf{3}$ & BBOB & 2 & 3 & 2 & 3 & 2 & 2.4 & Satisfactory \\
\hline $\mathbf{4}$ & BCOI & 2 & 2 & 3 & 2 & 4 & 2.6 & fair \\
\hline $\mathbf{5}$ & BGUC & 3 & 3 & 3 & 3 & 4 & 3.2 & Fair \\
\hline $\mathbf{6}$ & BIBI & 3 & 3 & 2 & 3 & 3 & 2.8 & Fair \\
\hline $\mathbf{7}$ & BIME & 3 & 2 & 3 & 2 & 4 & 2.8 & Satisfactory \\
\hline $\mathbf{8}$ & BKUI & 1 & 2 & 2 & 1 & 4 & 2 & Satisfactory \\
\hline $\mathbf{9}$ & BMNS & 3 & 3 & 3 & 3 & 4 & 3.2 & Fair \\
\hline $\mathbf{1 0}$ & BNOI & 4 & 4 & 2 & 4 & 3 & 3.4 & Fair \\
\hline $\mathbf{1 1}$ & BSUC & 3 & 4 & 2 & 4 & 3 & 3.2 & Fair \\
\hline $\mathbf{1 2}$ & BUND & 3 & 3 & 2 & 3 & 4 & 3 & Fair \\
\hline $\mathbf{1 3}$ & BUOI & 3 & 2 & 3 & 4 & 3 & 3 & Fair \\
\hline
\end{tabular}

\section{Asset Quality}

It is clear from Table (13) that Iraqi banks contain rigid assets that do not generate financial returns, weak management of the loan portfolio and lack of high diversification in the bank's financial portfolio. As well as the lack of diversity in the loans granted as most of the Iraqi banks do not rely on the loans diversity to almost note that they depend on the same pattern in the loans granting and the existence of competition between them in a variety of granting loans and this because of the routine and it has not a great freedom in grants Loans. Banks in this case also suffer from operational risks that the banks management must deal with quickly, especially those that fall within the margin classification. Otherwise, these banks will not be able to generate income to cover their expenses in the future.

Table (13): Assets quality

\begin{tabular}{lcccccccc}
\hline No. & Banks & EATA & TBPA & DA & TAEA & FIX & Average & Classification \\
\hline $\mathbf{1}$ & BASH & 4 & 3 & 4 & 3 & 2 & 3.2 & Fair \\
\hline $\mathbf{2}$ & BBAY & 3 & 3 & 5 & 3 & 2 & 3.2 & Fair \\
\hline $\mathbf{3}$ & BBOB & 3 & 4 & 4 & 4 & 2 & 3.4 & Fair \\
\hline $\mathbf{4}$ & BCOI & 3 & 3 & 3 & 2 & 1 & 2.4 & Satisfactory \\
\hline $\mathbf{5}$ & BGUC & 3 & 4 & 5 & 3 & 2 & 3.4 & Satisfactory \\
\hline $\mathbf{6}$ & BIBI & 4 & 3 & 4 & 4 & 2 & 3.4 & Satisfactory \\
\hline $\mathbf{7}$ & BIME & 3 & 3 & 4 & 3 & 3 & 3.2 & Fair \\
\hline $\mathbf{8}$ & BKUI & 2 & 2 & 2 & 2 & 1 & 1.8 & Satisfactory \\
\hline $\mathbf{9}$ & BMNS & 4 & 4 & 4 & 4 & 2 & 3.6 & Margin \\
\hline $\mathbf{1 0}$ & BNOI & 3 & 3 & 5 & 3 & 3 & 3.4 & Satisfactory \\
\hline $\mathbf{1 1}$ & BSUC & 4 & 4 & 5 & 3 & 3 & 3.8 & Margin \\
\hline $\mathbf{1 2}$ & BUND & 5 & 4 & 4 & 4 & 3 & 4 & Margin \\
\hline $\mathbf{1 3}$ & BUOI & 5 & 4 & 5 & 4 & 3 & 4.2 & Margin \\
\hline
\end{tabular}

\section{Efficiency Management}

By following the table (14) we note that there is a clear weakness of many banks in the management field. This weakness is represented by the management inability to adjust the banking policy on sound bases. This indicates that management has experienced a number of errors and that there are no plans to develop future banking policies. In all its equations, this indicator is based on the number of branches of each bank distributed throughout Iraq. Although these banks provided, however, when conducting the survey and information collection, we found that the number of branches are very few in the whole of Iraq as shown in Table (11). This is strong evidence that the current banks cannot meet the requests of customers. This is due to the lack of public awareness of the public towards banks, which 
made these banks limited to a very few numbers of branches and many of them has limited branches in some cities and the absence of the bank activity in other cities.

Table (14): Efficiency Management

\begin{tabular}{lcccccccc}
\hline No. & Banks & TPTB & TATB & TLTB & TDTB & TFTB & Average & Classification \\
\hline $\mathbf{1}$ & BASH & 3 & 3 & 3 & 4 & 4 & 3.4 & Fair \\
\hline $\mathbf{2}$ & BBAY & 2 & 2 & 3 & 4 & 3 & 2.8 & Fair \\
\hline $\mathbf{3}$ & BBOB & 3 & 4 & 4 & 4 & 3 & 3.6 & Margin \\
\hline $\mathbf{4}$ & BCOI & 2 & 3 & 4 & 3 & 3 & 3 & Fair \\
\hline $\mathbf{5}$ & BGUC & 3 & 3 & 3 & 4 & 4 & 3.4 & Fair \\
\hline $\mathbf{6}$ & BIBI & 2 & 3 & 2 & 4 & 4 & 3 & Fair \\
\hline $\mathbf{7}$ & BIME & 4 & 4 & 3 & 4 & 4 & 3.8 & Margin \\
\hline $\mathbf{8}$ & BKUI & 1 & 2 & 1 & 2 & 2 & 1.6 & Satisfactory \\
\hline $\mathbf{9}$ & BMNS & 2 & 3 & 3 & 5 & 4 & 3.4 & Fair \\
\hline $\mathbf{1 0}$ & BNOI & 4 & 3 & 4 & 5 & 5 & 4.2 & Margin \\
\hline $\mathbf{1 1}$ & BSUC & 4 & 4 & 5 & 4 & 5 & 4.4 & Margin \\
\hline $\mathbf{1 2}$ & BUND & 3 & 4 & 4 & 5 & 4 & 4 & Margin \\
\hline $\mathbf{1 3}$ & BUOI & 3 & 3 & 5 & 4 & 4 & 3.8 & \\
\hline & & & & & & & & \\
\hline
\end{tabular}

\section{Earnings}

Table (15) shows that Earnings achieved by banks is not within the required level. This means that the banks incur high expenses and have doubtful debts, which affected the decline in profits. And there is a lack of strong strategies at the bank to reduce costs. When reviewing several studies in the Iraqi environment, we did not find adequate studies to reduce costs at the level of banks. This also indicates risk in lending operations which reduced Earnings. This is also evidence of the existence of market risks and instability in the economic situation, which led banks to reduce the loans granting and reduce their Earnings, especially long-term loans.

Table (15): Earnings

\begin{tabular}{lcccccccc}
\hline No. & Banks & FTI & PF & PD & PP & OI & Average & Classification \\
\hline $\mathbf{1}$ & BASH & 4 & 2 & 2 & 3 & 3 & 2.8 & Fair \\
\hline $\mathbf{2}$ & BBAY & 3 & 2 & 2 & 3 & 3 & 2.6 & Fair \\
\hline $\mathbf{3}$ & BBOB & 3 & 2 & 2 & 3 & 2 & 2.4 & Satisfactory \\
\hline $\mathbf{4}$ & BCOI & 2 & 2 & 2 & 3 & 2 & 2.2 & Satisfactory \\
\hline $\mathbf{5}$ & BGUC & 4 & 3 & 3 & 4 & 3 & 3.4 & Fair \\
\hline $\mathbf{6}$ & BIBI & 4 & 2 & 3 & 3 & 3 & 3 & Fair \\
\hline $\mathbf{7}$ & BIME & 4 & 2 & 3 & 4 & 4 & 3.4 & Fair \\
\hline $\mathbf{8}$ & BKUI & 1 & 2 & 1 & 2 & 2 & 1.6 & Satisfactory \\
\hline
\end{tabular}




\begin{tabular}{lllllllcl}
\hline $\mathbf{9}$ & BMNS & 4 & 3 & 3 & 3 & 3 & 3.2 & Fair \\
\hline $\mathbf{1 0}$ & BNOI & 4 & 4 & 4 & 3 & 4 & 3.8 & Margin \\
\hline $\mathbf{1 1}$ & BSUC & 5 & 3 & 5 & 5 & 4 & 4.4 & Margin \\
\hline $\mathbf{1 2}$ & BUND & 4 & 3 & 4 & 4 & 5 & 4 & Margin \\
\hline $\mathbf{1 3}$ & BUOI & 4 & 2 & 3 & 5 & 4 & 3.6 & Margin \\
\hline
\end{tabular}

\section{Liquidity}

By following the table (16) we note that most banks suffer from a lack of liquidity and this is evident because of the realized low profits and the cost increase, as evidenced by the Earning index. This is due to the decline in long-term investments in Iraqi banks as most of their investments are short-term and a few of it is medium-term, this is due to the lack of financial experts with high experience or lack of data available to them to enter into long-term investments. This was reflected in lower liquidity. Most of the Iraqi banks have little investment in securities, mostly internal rather than international. We conclude that Iraqi banks are unable to cope with large withdrawals. As well as the inability of Iraqi banks to achieve an optimal investment of their total assets.

Table (16) Liquidity

\begin{tabular}{lcccccccc}
\hline No. & Banks & INT & VTC & OTA & VD & LI & Average & Classification \\
\hline $\mathbf{1}$ & BASH & 4 & 3 & 4 & 5 & 4 & 4 & Margin \\
\hline $\mathbf{2}$ & BBAY & 3 & 3 & 5 & 4 & 4 & 3.8 & Margin \\
\hline $\mathbf{3}$ & BBOB & 3 & 4 & 4 & 3 & 4 & 3.6 & Margin \\
\hline $\mathbf{4}$ & BCOI & 3 & 3 & 3 & 4 & 3 & 3.2 & Fair \\
\hline $\mathbf{5}$ & BGUC & 4 & 4 & 4 & 4 & 3 & 3.8 & Margin \\
\hline $\mathbf{6}$ & BIBI & 4 & 3 & 4 & 4 & 4 & 3.8 & Margin \\
\hline $\mathbf{7}$ & BIME & 4 & 3 & 4 & 5 & 4 & 4 & Satisfactory \\
\hline $\mathbf{8}$ & BKUI & 2 & 2 & 3 & 2 & 3 & 2.4 & Margin \\
\hline $\mathbf{9}$ & BMNS & 4 & 4 & 4 & 5 & 4 & 4.2 & Unsatisfactory \\
\hline $\mathbf{1 0}$ & BNOI & 4 & 5 & 5 & 5 & 5 & 4.8 & Margin \\
\hline $\mathbf{1 1}$ & BSUC & 4 & 4 & 4 & 5 & 5 & 4.4 & Margin \\
\hline $\mathbf{1 2}$ & BUND & 5 & 4 & 4 & 5 & 4 & 4.4 & Margin \\
\hline $\mathbf{1 3}$ & BUOI & 4 & 3 & 4 & 5 & 4 & 4 & \\
\hline
\end{tabular}

\section{Sensitivity to Market Risk}

Table (17) shows that Iraqi banks are currently exposed to high market risks. These risks may be represented by lower asset prices on the Bank's net worth. As well as the lack of diversity in the financial portfolios or lack of securities investment, it can be seen in Table (17). Also, the specific provisions to meet defaults are not within the required level. We note that the indicator (OPER) is within a bad level because of the lack of long-term investments of all Iraqi banks. Most Iraqi banks also have current deposits at a large rate and in some cases may reach be equal to the rest of the deposits or more.

Table (17): Sensitivity to Market Risk

\begin{tabular}{lcccccccc}
\hline No. & Banks & NPL & NPL2 & PROV & OPER & DD & Average & Classification \\
\hline $\mathbf{1}$ & BASH & 3 & 3 & 4 & 4 & 4 & 3.6 & Margin \\
\hline $\mathbf{2}$ & BBAY & 2 & 3 & 3 & 4 & 3 & 3 & Fair \\
\hline $\mathbf{3}$ & BBOB & 3 & 3 & 3 & 4 & 3 & 3.2 & Fair \\
\hline $\mathbf{4}$ & BCOI & 1 & 2 & 2 & 3 & 3 & 2.2 & Satisfactory \\
\hline $\mathbf{5}$ & BGUC & 3 & 3 & 4 & 4 & 4 & 3.6 & Margin \\
\hline $\mathbf{6}$ & BIBI & 3 & 3 & 4 & 4 & 3 & 3.4 & Fair \\
\hline $\mathbf{7}$ & BIME & 3 & 4 & 2 & 3 & 3 & 3 & Fair \\
\hline $\mathbf{8}$ & BKUI & 2 & 3 & 2 & 3 & 2 & 2.4 & Satisfactory \\
\hline $\mathbf{9}$ & BMNS & 3 & 3 & 3 & 4 & 4 & 3.4 & Fair \\
\hline
\end{tabular}




\begin{tabular}{ccccccccc}
\hline $\mathbf{1 0}$ & BNOI & 4 & 4 & 4 & 5 & 5 & 4.4 & Margin \\
\hline $\mathbf{1 1}$ & BSUC & 2 & 3 & 4 & 5 & 5 & 3.8 & Margin \\
\hline $\mathbf{1 2}$ & BUND & 3 & 2 & 3 & 5 & 4 & 3.4 & Fair \\
\hline $\mathbf{1 3}$ & BUOI & 3 & 3 & 3 & 5 & 3 & 3.4 & Fair \\
\hline
\end{tabular}

\section{CAMELS Index}

After we discussed the indexes in the previous tables we reach the final stage, which is the final score for each bank. Note from table (18) we find that most banks sample research did not reach the strong level but graduated from the Satisfactory, Fair, Marginal and this indicates that the banks within the classification (fair) include some weakness \& strength elements and it needs to be controlled and followed-up and develop considerable cost reduction programs. Banks in the Margin are at risk and may lead to failure. These banks need to develop reform and follow-up programs as soon as possible to not reach financial failure. Iraqi banks need to review the types of provided loans. Note from the table (18) that the bank (BKUI) is the only bank that is better off than the rest of the banks because the bank is located within the Kurdistan region of Iraq and has good administrative cadres. The northern region is also witnessing more political and economic stability than the rest of Iraq, which has contributed to making the bank in a satisfactory classification.

\begin{tabular}{lccccccccc}
\multicolumn{10}{c}{ Table (18): CAMELS Index } \\
\hline No. & Banks & C & A & M & E & L & S & Average & Classification \\
\hline $\mathbf{1}$ & BASH & 2.3 & 3.2 & 3.4 & 2.8 & 4 & 3.6 & 3.2 & Fair \\
\hline $\mathbf{2}$ & BBAY & 3.2 & 3.2 & 2.8 & 2.6 & 3.8 & 3 & 3.1 & Fair \\
\hline $\mathbf{3}$ & BBOB & 2.4 & 3.4 & 3.6 & 2.4 & 3.6 & 3.2 & 3.1 & Fair \\
\hline $\mathbf{4}$ & BCOI & 2.6 & 2.4 & 3 & 2.2 & 3.2 & 2.2 & 2.6 & Fair \\
\hline $\mathbf{5}$ & BGUC & 3.2 & 3.4 & 3.4 & 3.4 & 3.8 & 3.6 & 3.4 & Fair \\
\hline $\mathbf{6}$ & BIBI & 2.8 & 3.4 & 3 & 3 & 3.8 & 3.4 & 3.2 & Fair \\
\hline $\mathbf{7}$ & BIME & 2.8 & 3.2 & 3.8 & 3.4 & 4 & 3 & 3.3 & Fair \\
\hline $\mathbf{8}$ & BKUI & 2 & 1.8 & 1.6 & 1.6 & 2.4 & 2.4 & 1.9 & Satisfactory \\
\hline $\mathbf{9}$ & BMNS & 3.2 & 3.6 & 3.4 & 3.2 & 4.2 & 3.4 & 3.5 & Margin \\
\hline $\mathbf{1 0}$ & BNOI & 3.4 & 3.4 & 4.2 & 3.8 & 4.8 & 4.4 & 4 & Margin \\
\hline $\mathbf{1 1}$ & BSUC & 3.2 & 3.8 & 4.4 & 4.4 & 4.4 & 3.8 & 4 & Margin \\
\hline $\mathbf{1 2}$ & BUND & 3 & 4 & 4 & 4 & 4.4 & 3.4 & 3.8 & Margin \\
\hline $\mathbf{1 3}$ & BUOI & 3 & 4.2 & 3.8 & 3.6 & 4 & 3.4 & 3.6 & Margin \\
\hline
\end{tabular}

\section{Conclusion}

The CAMELS standard contributed to detect and identify the negative points of the Iraqi banks because of their lack of a modern evaluation system that reveals the banks weaknesses and treats it. We have found that the long-term investments of Iraqi banks are very few, which indicates that they cannot provide support for industrial projects in the long-term. Also, the investment of Iraqi banks in securities is not at that level and that most of their investments are in local securities and almost international investments barely exist. They also do not have a variety of portfolios, which makes banks unable to cope with market risks. It is important to find that the sample banks branches of the research in Iraq is very few and does not fit the current situation. This requires the banks to set up new branches and diversify their services.

The CAMELS standard analyzes the bank's performance and compares it with the industry level in the banking environment, which helps to formulate a policy and plans for management and focus on the negative elements. Most banks cannot face withdrawals on deposits during a short period and in large 
quantities. The profitability of banks was also not within a strong level and this raises the question of the absence of any bank on the first level.

The application of the CAMELS standard is to support the bank's efficiency and effectiveness. There should be a unified database for all banks, in which all the details and numbers required to know the position of the bank through the equations that we applied, in order to know the position of the bank. The database for each bank should be directly linked with the CBI and updated continuously through the synchronization technology in order to address the deviations that occur in the banks. Banks are the most sensitive to risk and this requires disclosure of all data. Preparing the research, we have a difficulty of the data lack for a number of banks; however, in 2019, we did not get full data for a number of banks only for the year 2017.

The Central Bank should exercise its oversight role through office and field controls. And shall be a central database so that banks that fail to disclose their data are fully identified. The Central Bank should establish training courses in the field of banking evaluation and control and the development of technical capabilities in order to reach an efficient banking system and the necessity of obligating all banks to implement the CAMELS standard. We also find that it is better for a number of banks that cannot rise to a better level to merge with each other or merge with other top-level banks in order to be able to face market risks. Banks must work to increase profitability by employing deposits and exploiting liquidity and investing them. And encourage individuals to place time deposits by offering acceptable benefits on these deposits. Banks should increase their capital in proportion to the volume of deposits and assets in order to reduce banks risks and address credit concentrations within the banks investment portfolios and improve the bank assets quality and reduce the losses suffered by the bank due to troubled assets. As well as the need to use a special department to manage all types of risks.

\section{References}

\section{Books}

Al-Amin, Qasimi Mohammed. (2010). Measuring the efficiency of Algerian banks using the CAMELS model. Master Thesis. University of Qasdi Mrabah-Ouargla / Faculty of Economic Sciences, Commercial Sciences and Management Sciences. Department of Economic Sciences of Algeria. 1-73.

AL-Imam, Salahuddin Muhammad Amin. (2010). Use the CAMELS rating system to achieve financial safety for banks. Al - Mansour Magazine. Baghdad. No. 13. 1-33.

Al-Mahmoud, Hussein. (2014). The possibility of using the CAMELS system in assessing the quality of profitability in Islamic banks. Master Thesis. Damascus University, Faculty of Economics.

Al-Qaisi and Fawzan Abdul Qader. (2017). Analysis of factors affecting the performance of commercial banks using the CAMELS model. Jordanian Journal of Business Administration. Volume 13. Issue 4. 461-474.

Al-Reda, Saba Abdel-Hadi, Basri, Abd El-Rida Shafiq. (2011). CAMELS matrix in the evaluation of the performance of banks, Journal of accounting and financial studies. Volume 6. Issue 6. 172-185. 
Al-saaeh, Bouzid. (2012). Ways to strengthen accountability and transparency to combat corruption and enable good governance in Arab countries. Journal of the researcher. Algeria. 5566.

Al-Tai, Saji Fathi Mohammed, and Mohamed, Leila Abdel-Karim. (2013). Forecasting bank crises using the CAMELS standard. Tikrit Journal of Administrative and Economic Sciences. Volume 9. Issue 27. 162-193.

Aspal, P. K., \& Dhawan, S. (2016). Camels Rating Model For Evaluating Financial Performance of Banking Sector: A Theoretical Perspective. International Journal of System Modeling and Simulation, 1(3), 10-15.

Brandimarte, P. (2013). Numerical methods in finance and economics: a MATLAB-based introduction. John Wiley \& Sons.

Britch, S. C., Binepal, Y. S., Ruder, M. G., Kariithi, H. M., Linthicum, K. J., Anyamba, A., ... \& Gacheru, S. (2013). Rift Valley fever risk map model and seroprevalence in selected wild ungulates and camels from Kenya. PLoS One, 8(6), e66626.

Çağlar, A. (2018). Financial performance of banks in turkey: an investigation with to dim method1. FINANCE \& ECONOMETRICS, 9.

Dahir, Hanan. (2015). The impact of the merger and acquisition of the financial performance of the bank. Tishreen University Journal for Research and Scientific Studies - Economic and Legal Sciences Series, vol. 37, no. 3. 125-144.

Dang, U. (2011). The CAMEL rating system in banking supervision. A case study.

Debik, Hani Ahmed Mahmoud. (2015). The relationship between the application of the capital adequacy standard in accordance with the decisions of the Basel Committee and the profitability of local commercial banks in Palestine. Master Thesis. Islamic University. Commerce College. Accounting and Finance Department. 1-130.

Derviz, A., \& Podpiera, J. (2008). Predicting bank CAMELS and S\&P ratings: the case of the Czech Republic. Emerging Markets Finance and Trade, 44(1), 117-130.

Desta, T. S. (2016). Financial performance of "The best African banks": A comparative analysis through CAMEL rating. Journal of accounting and management, 6(1), 1-20.

Dinçer, H., Hacioğlu, Ü., \& Yuksel, S. (Eds.). (2018). Global Approaches in Financial Economics, Banking, and Finance. Springer International Publishing.

Dincer, H., Yuksel, S., \& Hacioglu, U. (2015). CAMELS-based Determinants for the Credit Rating of Turkish Deposit Banks. International Journal of Finance \& Banking Studies, 4(4), 
Dirheb, Mohamed Samir. (2010). Bank Risk Assessment System (CAMELS). Iraqi Journal of Administrative Sciences. Vol. 11. No. 15. 260-300.

Drummond, P. F. N. (2000). Former Yugoslav Republic of Macedonia Banking Soundness and Recent Lessons (No. 2000-2145). International Monetary Fund.

Ghasempour, S., \& Salami, M. (2016). Ranking Iranian private banks based on the CAMELS model using the AHP hybrid approach and TOPSIS. International Journal of Academic Research in Accounting, Finance and Management Sciences, 6(4), 52-62.

Gilbert, R. A., Meyer, A. P., \& Vaughan, M. D. (2002). Could a CAMELS downgrade model improve off-site surveillance? Federal Reserve Bank of St. Louis Review, 84(January/February 2002).

Githinji, D. W. (2010). Relationship between financial performance and camel rating of commercial banks in Kenya. Unpublished Project University of Nairobi.

Handorf, W. C. (2016). CAMEL to CAMELS: The risk of sensitivity. Journal of Banking Regulation, 17(4), 273-287.

Huynh, H. T., \& Soumare, I. (2011). Stochastic simulation and applications in finance with MATLAB programs (Vol. 633). John Wiley \& Sons.

Khodashahi, M., Rahimi, E., \& Bagheri, V. (2018). Earthquake-Induced Landslides Hazard Zonation of Rudbar-Manjil Using CAMEL Model. Geotechnical and Geological Engineering, 1-22.

Kienitz, J., \& Wetterau, D. (2012). Financial modeling: Theory, implementation, and practice with MATLAB source. John Wiley \& Sons.

Masood, O., Ghauri, S. M. K., \& Aktan, B. (2016). Predicting Islamic banks performance through CAMELS rating model. Banks and Bank Systems, 11(3), 37-43.

McCarthy. (2018). Foundations of Computational Finance with MATLAB, John Wiley \& Sons.

Muralidhara, P., \& Lingam, C. (2017). Camel Model As An Effective Measure of Financial Performance of Nationalised Banks. International Journal of Pure and Applied Mathematics, 117(7), 255-262.

Nicolae, B., \& Maria-Daciana, R. C. (2014). Study regarding the financial stability of commercial banks listed on Bucharest Stock Exchange of CAMELS rating outlook. Journal of International Studies, 7(3), 133-143.

Rahim, Abbas Fadel. (2014). The importance of CAMELS in assessing the performance of banks in Iraq. A case study on the National Islamic Bank, Journal of Baghdad College of Economic Sciences University. No. 39. 26-57. 
Rahman, M. Z., \& Islam, M. S. (2018). Use of CAMEL Rating Framework: A Comparative Performance Evaluation of Selected Bangladeshi Private Commercial Banks. International Journal of Economics and Finance, 10(1), 120-128.

Rauf, Ahamed Lebbe Abdul. (2016). Towards Increasing the Financial Performance: An Application of CAMEL Model in Banking Sector in the Context of Sri Lanka, Research Journal of Finance and Accounting, Vol 7, No 5. 66-71.

Rostami, M. (2015). Determination of Camels model on bank's performance. International journal of multidisciplinary research and development, 2(10), 652-664.

Rozzani, N., \& Rahman, R. A. (2013). Camels and performance evaluation of banks in Malaysia: conventional versus Islamic. Journal of Islamic Finance and Business Research, 2(1), 36-45.

Sarker, A. (2005). CAMELS rating system in the context of Islamic banking: A proposed 'S'for Shariah framework. Journal of Islamic Economics and Finance, 1(1), 78-84.

Sarker, A. (2005). CAMELS rating system in the context of Islamic banking: A proposed 'S'for Shariah framework. Journal of Islamic Economics and Finance, 1(1), 78-84.

Shaddady, A., \& Moore, T. (2019). Investigation of the effects of financial regulation and supervision on bank stability: The application of CAMELS-DEA to quantile regressions. Journal of International Financial Markets, Institutions, and Money, 58, 96-116.

Shakara, Mowafaq Abbas Baqir. (2012). Assess the performance of banks under CAMELS standards. Journal of Accounting and Financial Studies, Vol. 7, No. 18. 134-154.

Triaa, Hanan. (2015). The importance of the CAMELS system in assessing the performance of commercial banks. Master Thesis, University of Shaheed Hama Lakhdar Balwadi, Faculty of Economic and Commercial Sciences and Management Sciences. Department of Economics. Algeria. $1-130$.

Valahzaghard, M., \& Bahrami, M. (2013). Prediction of default probability in banking industry using CAMELS index: A case study of Iranian banks. Management Science Letters, 3(4), 1113-1118.

Williams, H. T. (2011). Determinants of capital adequacy in the Banking Sub-Sector of the Nigeria Economy: Efficacy of Camels. (A Model Specification with Co-Integration Analysis). International Journal of Academic Research in Business and Social Sciences, 1(3), 233.

Zagoud, Eman. (2015). Early warning using the CAMELS model to assess the performance of commercial banks. Master of Science, Al-Arabi Bin Mihaidi University, Umm Al-Bawaki, Faculty of Economic Sciences, Commercial Sciences and Management Sciences. Algeria. 1-165. 


\section{Copyrights}

Copyright for this article is retained by the author(s), with first publication rights granted to the journal. This is an open-access article distributed under the terms and conditions of the Creative Commons Attribution license (http://creativecommons.org/licenses/by/4.0/). 